\title{
ILF2 wt Allele
}

National Cancer Institute

\section{Source}

National Cancer Institute. ILF2 wt Allele. NCI Thesaurus. Code C140308.

Human ILF2 wild-type allele is located in the vicinity of $1 \mathrm{q} 21.3$ and is approximately $9 \mathrm{~kb}$ in length. This allele, which encodes interleukin enhancer-binding factor 2 protein, is involved in DNA repair, mRNA localization, the modulation of IL2 gene expression. 